\title{
GERAKAN KOMUNITAS ACEH GO OPEN SOURCE SEBAGAI UPAYA PENGENDALIAN PRODUK HALAL BERBASIS TEKNOLOGI INFORMASI PADA MADRASAH ALIYAH BANDA ACEH DAN ACEH BESAR
}

\author{
Andika Prajana1, Khairan AR ${ }^{1}$, Hendri Ahmadian' ${ }^{1}$, Hendy Mizuardy ${ }^{1}$ \\ ${ }^{1}$ Universitas Islam Negeri Ar-Raniry Banda Aceh, Aceh, Indonesia \\ andikaprajana@ar-raniry.ac.id
}

\begin{abstract}
Abstrak: Penggunaan perangkat lunak bajakan menjadi budaya baru di kalangan anak muda Indonesia khususnya pelajar-pelajar yang berada di bawah naungan Kementerian Agama mulai dari tingkat Raudhatul Athfal (RA) sampai Perguruan Tinggi Keagamaan Islam Negeri (PTKIN). Peneliti menemukan suatu masalah yang dihadapi kalangan remaja atau pelajar yaitu kurangnya pengetahuan terhadap teknologi, kurangnya pengetahuan terhadap aspek hukum dan nilai-nilai keislaman. Penelitian ini dilakukan dengan cara kegiatan pengabdian, sosialisasi dan pembentukan komunitas Aceh Go Open Source di Madrasah Aliyah Negeri (MAN)/swasta di Kabupaten Aceh Besar dan Kota Banda Aceh. Metode yang digunakan adalah metode Knowledge Sharing sebagai proses pengkomunikasian dan pertukaran pengetahuan dari satu individu ke pada individu. Hasil yang diperoleh dari pengabdian berbasis riset ini adalah terbentuknya komunitas kalangan remaja. Selanjutnya efektifitas community leader, organization structure, religious, social trust, share vision tidak memiliki pengaruh terhadap knowlege sharing. Sedangkan individual motivation sangat berpengaruh terhadap knowledge sharing yang mengindikasikan bahwa motivasi personal menjadi dorongan utama terbentuknya Komunitas Aceh Go Open source ini.
\end{abstract}

Kata Kunci: open source, knowledge sharing, komunitas

\begin{abstract}
The use of pirated software has become a new culture among Indonesian youth, especially students under the Ministry of Religion Affairs' auspices, from primary levels to higher education. We found a problem faced by adolescents or students, namely a lack of knowledge of technology, legal aspects, and Islamic values. This research was conducted in the form of community service activities, socialization, and the formation of the Aceh Go Open Source community at Madrasah Aliyah in Aceh Besar District and Banda Aceh City. The method used was Knowledge Sharing as a process of communicating and exchanging knowledge from one individual to another. The results of this community services-based research are the formation of a community among adolescents. The community leaders, organization structures, religious, social trust, share vision do not influence knowledge sharing. Meanwhile, individual motivation is very influential on knowledge sharing, which indicates that personal motivation is the main driver for forming the Aceh Go Open Source Community.
\end{abstract}

Keywords: open source, knowledge sharing, community

\section{Pendahuluan}

Business Software Alliance melaporkan bahwa dalam kurun waktu enam tahun yakni sejak tahun 2011-2017, kerugian yang disebabkan oleh pembajakan perangkat lunak di Indonesia mencapai 5.170 juta dollar Amerika, survei ini menempatkan Indonesia sebagai negara ke-tiga yang mengalami kerugian terbesar akibat perangkat lunak bajakan di kawasan Asia Pasifik, di bawah china dan india yakni sebesar 33.168 juta dollar Amerika dan 10.999 juta dollar (Business Software Alliance, 2017).

Banyak teori yang menyebabkan masyarakat memilih perangakat lunak bajakan dan tingkat pembajakan perangkat lunak memiliki hubungan yang signifikan dengan pendapatan 
Gross Domestic Product Per Capita (GDPpc) suatu negara (Gopal \& Sanders, 1998; Marron \& Steel, 2000; Goel \& Nelson, 2009). Namun dari pengamatan dan survei yang peneliti lakukan, terdapat salah satu variabel yang menyebabkan maraknya penggunaan perangkat lunak bajakan yakni kurangnya pengetahuan sejak dini tentang bahaya laten terhadap penggunaan perangkat lunak bajakan tersebut. Setidaknya hal ini peneliti temukan dari hasil wawancara dan survey kepada 30 mahasiswa yang penulis didik pada Program Studi Teknologi Informasi (TI) dan Program Studi Pendidikan Teknologi Informasi (PTI) UIN Ar-Raniry Banda Aceh pada tahun akademik 2019/2020.

Hasil wawancara dan survey tersebut berhasil mengungkap bahwa 21 mahasiswa dari 30 mahasiswa tamatan madrasah aliyah negeri/swasta yang peneliti survei pernah mendengar tentang perangkat lunak bajakan, dan sisanya sembilan orang menjawab belum pernah mendengar tentang perangkat lunak bajakan. Namun yang mengejutkan, lebih dari setengah dari 21 mahasiswa tersebut menjawab bahwa mereka tidak tahu sumber perangkat lunak bajakan yang mereka gunakan. Artinya, rata-rata mahasiswa pernah mendengar istilah perangkat lunak bajakan, namun tidak mengetahui dan memahami informasi lebih lanjut tentang dari mana sumber serta apa sebenarnya perangkat lunak bajakan tersebut.

Survei yang penulis lakukan tersebut berkorelasi dengan dengan hasil penelitian yang dilakukan Majid, Vivianie, \& Yusuf (2018) pada mahasiswa Fakultas Tarbiyah dan Keguruan UIN Ar-Raniry Banda Aceh. Mereka melaporkan bahwa 34\% mahasiswa Tarbiyah dan Keguruan UIN Ar-Raniry Banda Aceh yang menjadi responden penelitian mereka tidak mengetahui bahwa perangkat lunak yang mereka gunakan sehari-hari adalah perangkat lunak bajakan.

Salah satu faktor masih tingginya penggunaan perangkat lunak bajakan pada ligkup siswa di daerah Aceh, khususnya siswa Madrasyah adalah karena harga perangkat lunak berbayar masih terlalu tinggi. Sebagai contoh, harga saah satu perangkat lunak yang banyak digunakan oleh siswa yakni MS Office untuk keperluan pribadi berada di kisaran Rp. 959.999 per tahun (microsoft.com). Tentu saja harga tersebut cukup mahal bagi sekolah, lebih-lebih lagi bagi siswa. Pada sisi lain, ketidaktahuan siswa mengenai perangkat lunak open source sebagai pengganti perangkat lunak berbayar yang tentu saja memiliki spesifikasi sama dengan perangkat lunak yang penulis contohkan menjadi penguat alasan bagi siswa nyaman menggunakan perangkat lunak bajakan (Majid, Vivianie, \& Yusuf, 2018). Padahal, sejatinya perangkat lunak open source tidak kalah unggul dibandingkan dengan perangkat lunak berbayar, sebagai contoh perangkat lunak Open Office atau Liber Office yang merupakan perangkat lunak yang sangat baik sebagai perangkat lunak pengolahan kata layaknya MS Office. Disamping itu, penggunaan perangkat lunak bajakan merupakan tindakan yang bertentangan dengan syariat islam, sebagaimana termaktub pada Al-Qur'an Surat Asy-Syu'ara Ayat 183.

$$
\text { وَلَا تَبْخَسُوا النَّاسَ أَشْيَاءَهُمْ وَلَا تَعْثَوْا فِي الَأَرْضِ مُفْسِدِينَ }
$$

Artinya: "Dan janganlah kamu merugikan manusia pada hak-haknya dan janganlah kamu merajalela di muka bumi dengan membuat kerusakan". Pada ayat lain yaitu Surat An-Nisa Ayat 29 Allah SWT juga berfirman:

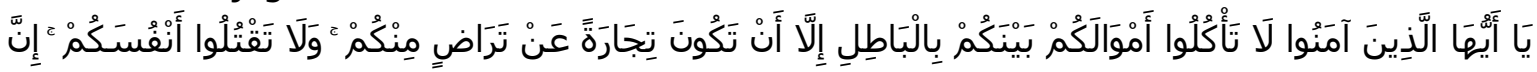

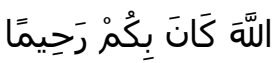


Artinya: "Hai orang-orang yang beriman, janganlah kamu saling memakan harta sesamamu dengan jalan yang batil, kecuali dengan jalan perniagaan yang berlaku dengan suka sama-suka di antara kamu. Dan janganlah kamu membunuh dirimu; sesungguhnya Allah adalah Maha Penyayang kepadamu".

Berdasarkan pada dua ayat tersebut, jelas bahwa Allah SWT pada Ayat tersebut mengingatkan kita agar tidak merugikan orang lain dengan mengambil hak-haknya. Sebagaimana kita ketahuai bahwa, penggunaan perangkat lunak bajakan merupakan tindakan pengambilan hak orang lain tanpa izin, sehingga kita diharuskan untuk menghindari hal tersebut. Sehingga, pelatihan penggunaan perangkat lunak open source sangat penting diselenggarakan, karena selain untuk mengatasi ketidaktahuan siswa-siswa Madrasyah mengenai perangkat lunak open source, juga sebagai langkah antisipasi kita selaku tenaga akademisi untuk mengedukasi siswa agar tidak terjerumus pada dosa dengan menggunkan perangkat lunak berbayar yang tentu saja sangat dilarang oleh Allah SWT.

Melihat dari permasalahan yang telah dijelaskan di atas, ini mengindikasikan UIN ArRaniry Banda Aceh sebagai salah satu perpanjangan tangan dari Kementrian Agama RI dalam corong pendidikan harus mengambil langkah strategis guna mengentaskan permasalahan penyalahgunaan perangkat lunak bajakan ini. Salah satu langkah yang dapat ditempuh oleh UIN Ar-Raniry Banda Aceh adalah dengan menggerakkan program studi (prodi) di bawah binaannya yang berlatar belakang teknologi (Prodi. Teknologi Informasi), syariah (Prodi. Ilmu Hukum), dan keagamaan (Ushuluddin) untuk melakukan sosialisasi serta pelatihan teknologi open source berbasis hukum dan keislaman secara masif kepada siswa-siswa MAN/Swasta di Aceh.

\section{Metode}

Metode pengabdian yang dilakukan merupakan pendekatan berbasis pembangunan komunitas yang biasa dikenal dengan istilah Assets Based Community Development (ABCD) dengan menitikberatkan pada bagian pembangunan teknologi, sumberdaya manusia, dan pendekatan spiritual (R W Wulandari dan N Maryani, 2020), dengan tujuan akhir adalah terciptanya sistem komunitas open source antar siswa madraysah di aceh yang berkesinambungan. Pembangunan teknologi dilakukan dengan membuat website komunitas sebagai sarana dalam berbagi pengetahuan tentang penguasaan perangkat lunak open source yang dalam hal ini menitikberatkan pada peran aktif siswa selaku sumber daya utama. Sementara itu, pendekatan spiritual dilakukan untuk memberikan pemahaman lebih lanjut kepada siswa mengenai aturan-aturan hukum umum dan nilai-nilai keislaman yang berkaitan dengan penggunaan perangkat lunak, yang dilaksanakan pada tahapan sosialisasi dan workshop penggunaan perangkat lunak open source. Proses pengabdian sendiri dilaksanakan dalam rentang waktu bulan juli sampai oktober 2020. Sementara itu, proses pengabdian mengikuti langkah seperti yang terlihat pada diagram di bawah ini. 


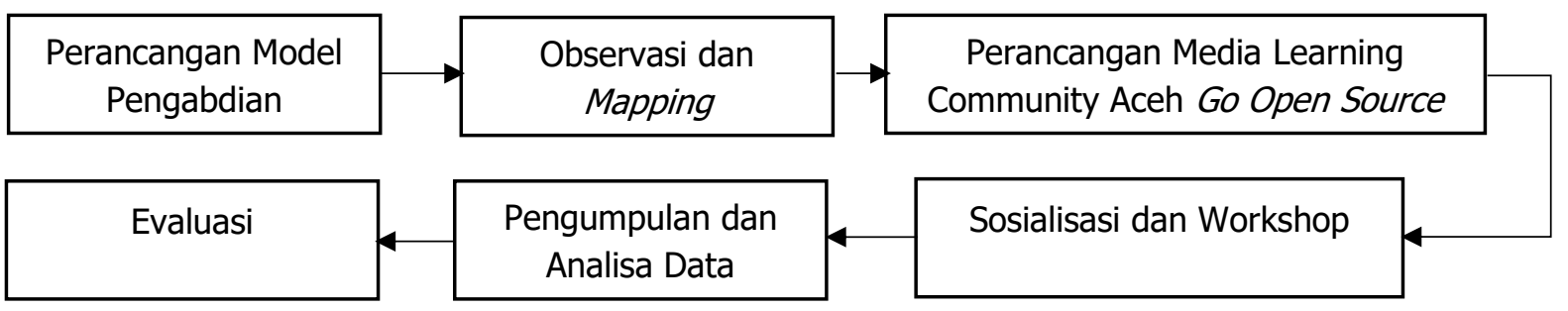

Gambar 1. Alur Metode Penelitian

\section{Model Pengabdian}

Pada pengabdian ini, akan dimanfaatkan media transfer pengetahuan berupa media pembelajaran komunitas berbasis web dan mobile chatting yang peneliti kenalkan dengan istilah media learning community (MLC). Hal ini dilakukan membantu proses knowledge sharing antara anggota komunitas open source yang dibentuk. Secara ringkas model pengabdian dapat dilihat pada Tabel 1.

Tabel 1. Model Pengabdian Masyarakat

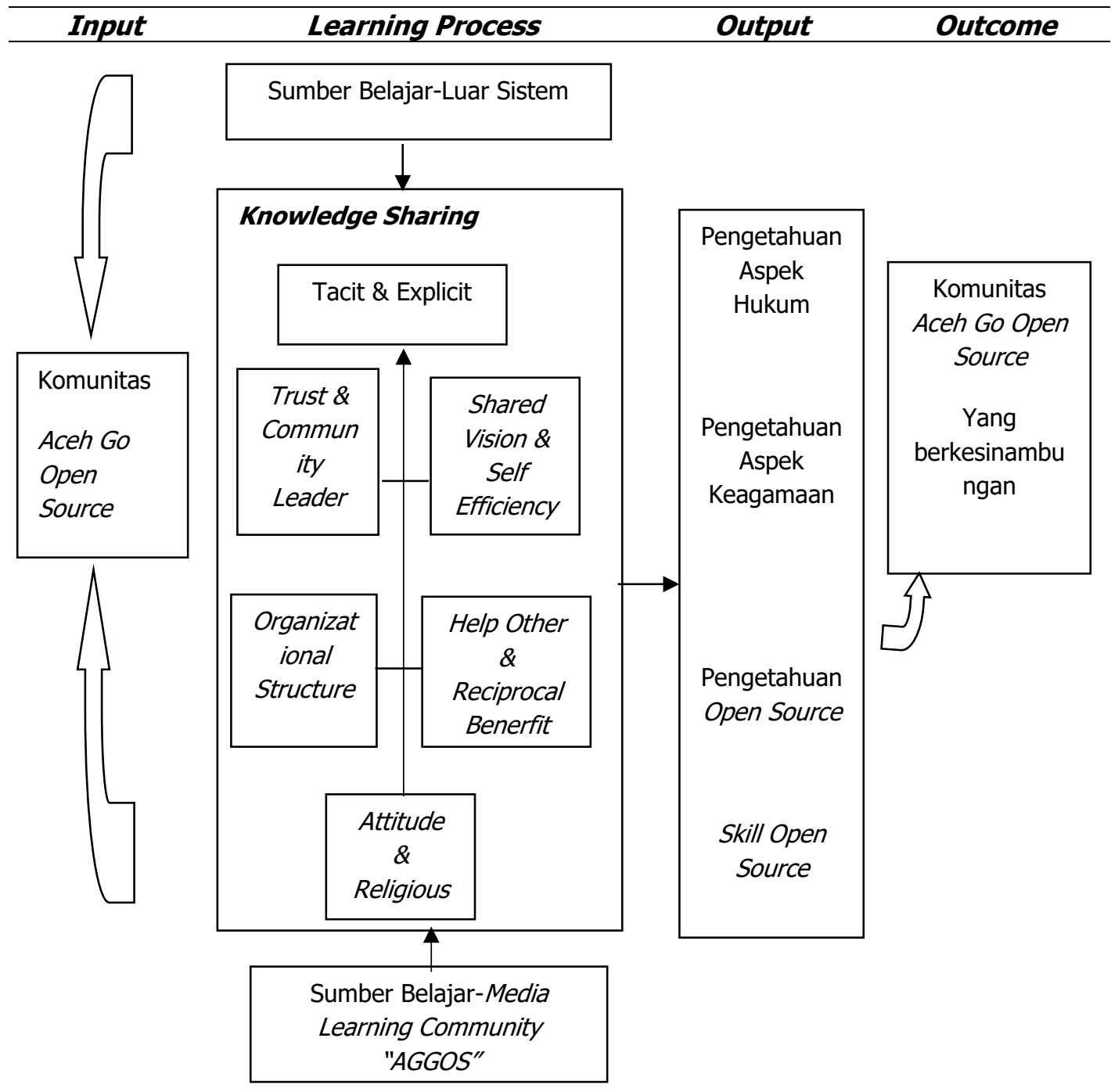




\section{Perancangan Media Learning Community (MLC) Aceh Go Open Source (AGOS)}

Media Learning Community (MLC) Aceh Go Open Source digunakan dengan dua pendekatan yakni: (1) melalui perangkat lunak berbasis web, dan (2) melalui perangkat lunak mobile chatting. Perangkat lunak berbasis web menggunakan platform wordpress. Wordpress peneliti pilih karena merupakan salah satu platform website nomor satu di dunia dan bersifat open source. Sedangkan untuk mobile chatting penulis menggunakan instant messenger Whatsapp sebagai media pemberian informasi dan pengganti tatap muka (Prajana, 2017).

\section{Pengumpulan dan Analisis Data}

Beberapa langkah pengumpulan dan analisis data yang dilakukan dalam penelitian ini adalah sebagai berikut:

1. Pembagian Instrumen Penelitian ke anggota komunitas

2. Pembuatan kisi-kisi Instrumen (Social Trust, Shared Vision, Individual Motivation, Organizational Structure, Community Leader, Religious, dan Knowledge Sharing)

3. Evaluasi Model Pengukuran

4. Pengujian validitas konvergen dan diskriminan, pengujian R-Square (R2), Effect Size (f2), dan Nilai Stone Geisser/Predictive Relevance (Q2) (Ukhisia, Astuti, \& Hidayat, 2013)

\section{Hasil dan Pembahasan}

Tujuan utama diadakannya pengabdian ini adalah untuk menciptakan komunitas pengguna perangkat lunak open souce di lingkup siswa madrasah Provinsi Aceh. Sebagaimana yang telah penulis sampaikan pada latar belakang, bahwa penggunaan perangkat lunak open souce dimaksudkan untuk membiasakan siswa-siswa yang tergabung dalam komunitas agar dapat mengetahui, kemudian saling berbagi, dan pada akhirnya menguasai dan terbiasa dalam menggunakan perangkat lunak open souce. Sehingga konsep pengabdian yang penulis angkat adalah dengan mengedepankan teori berbagi pengetahuan (knowledge sharing) yang berpusat pada pengetahuan open souce yang dimiliki oleh siswa serta keinginan berbagi mengenai informasi penggunaan perangkat lunak open souce yang dikuasai siswa dalam komunitas tersebut. Selain itu, pengabdian ini juga bertujuan mengukur tingkat efektivitas pembentukan komunitas tersebut ditinjau dari aspek-aspek teori knowledge sharing.

Langkah awal yang penulis lakukan adalah dengan merancang model pengabdian yang didasarkan pada teori-teori Knowledge Sharing yang terdiri atas lima variabel yakni: Trust \& Community Leader, Shared Vision \& Self Efficiency, Organizational Structure, Help Other \& Reciprocal Benerfit, dan Attitude \& Religious. Lima variabel tersebut ditujukan selain sebagai dasar penyusunan instrumen pengabdian, sehingga ditemukan variabel-variabel yang memiliki tingkat efektivitas yang baik dalam membentuk komunitas open souce bagi siswa madrasah di Aceh.

Setelah proses penentuan variabel terlaksana, selanjutnya penulis melakukan pelaksanaan sosialisasi penggunaan perangkat lunak open source yang terdiri atas sisi teoritis dan sisi praktis yakni: sosialisasi aspek legalitas/hukum positif Indonesia terhadap pengguna 
perangkat lunak bajakan, juga termasuk di dalamnya aspek-aspek hukum islam yang merupakan representatif nilai-nilai religiusitas. Sementara itu, tataran praktis terdiri atas: bagaimana memberikan pengetahuan dasar tentang penggunaan perangkat lunak open source ke siswa-siswa madrasah yang tergabung pada komunitas yang dibentuk.

Agar proses sosialisasi tersebut dapat berjalan sebagaimana mestinya, penulis didampingi oleh mahasiswa Prodi. Teknologi Informasi UIN Ar-Raniry Banda Aceh melakukan kegiatan seminar dengan mendatangkan narasumber-narasumber yang memiliki kompetensi terhadap tema sosialisasi yang diangkat. Seminar dilakukan dengan dengan mengundang seluruh siswa yang telah teregistrasi sebagai anggota komunitas open souce. Sementara itu, untuk menjaring siswa lain agar tertarik untuk bergabung pada komunitas, penulis membagikan selebaran flayer yang dibagikan secara online serta memanfaatkan media Chatting Room WhatsApp seperti terlihat pada gambar 2 dan pada gambar 3 di bawah ini.

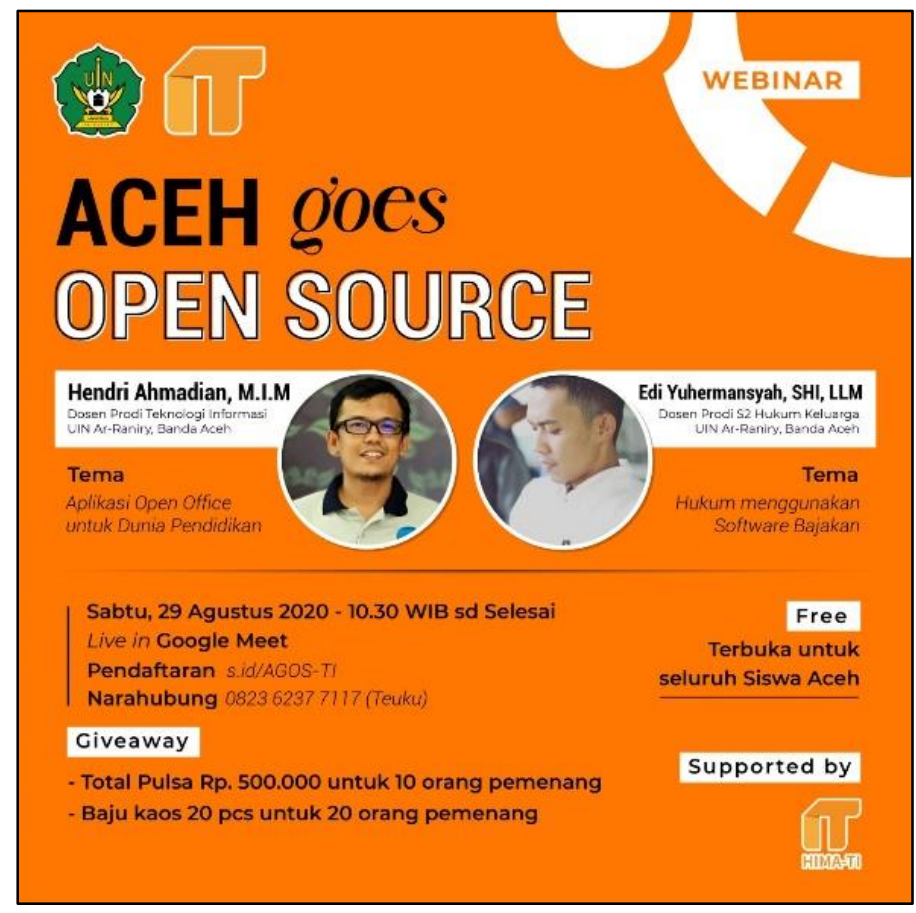

Gambar 2. Flayer seminar

Sementara itu, sebagai upaya dalam menerapkan protokol kesehatan di masa pandemi, penulis dan mahasiswa pendamping menyelenggarakan acara seminar online (Webinar). Proses webinar penulis laksanakan pada hari sabtu, tanggal 29 Agustus 2020. Setelah sebelumnya dilakukan rangkaian pembentukan panitia yang melibatkan enam orang mahasiswa Prodi. Teknologi Informasi UIN Ar-Raniry Banda Aceh, sebagaimana yang telah penulis jelaskan sebelumnya sebagai mahasiswa pendamping. Persiapan webinar dilakukan secara resmi dengan terlebih dahulu membuat surat undangan yang ditujukan kepada sekolah-sekolah yang siswanya diundang untuk menghadiri acara webinar tersebut. Selanjutnya, penitia memastikan kesiapan narasumber untuk memaparkan materi dengan meminta slide presentasi. Berikut penulis perlihatkan hasil tangkapan layar proses seminar yang ditunjukkan pada gambar $4 \mathrm{di}$ bawah ini. 


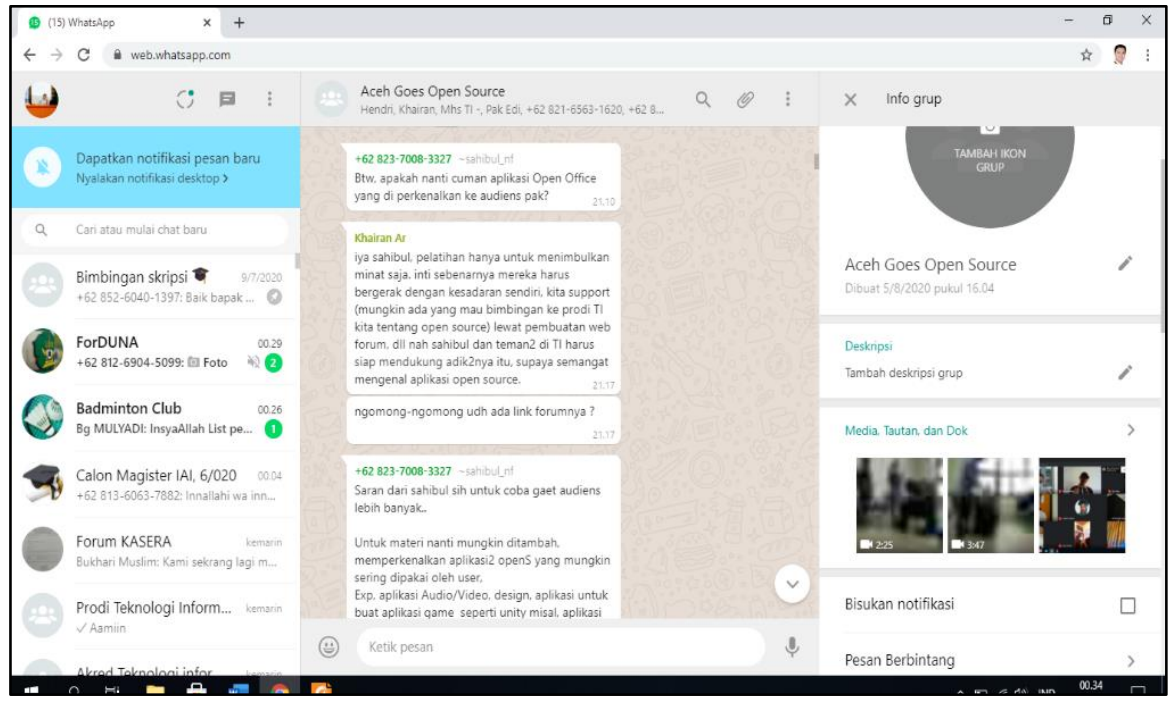

Gambar 3. Chatting Room WhatsApp
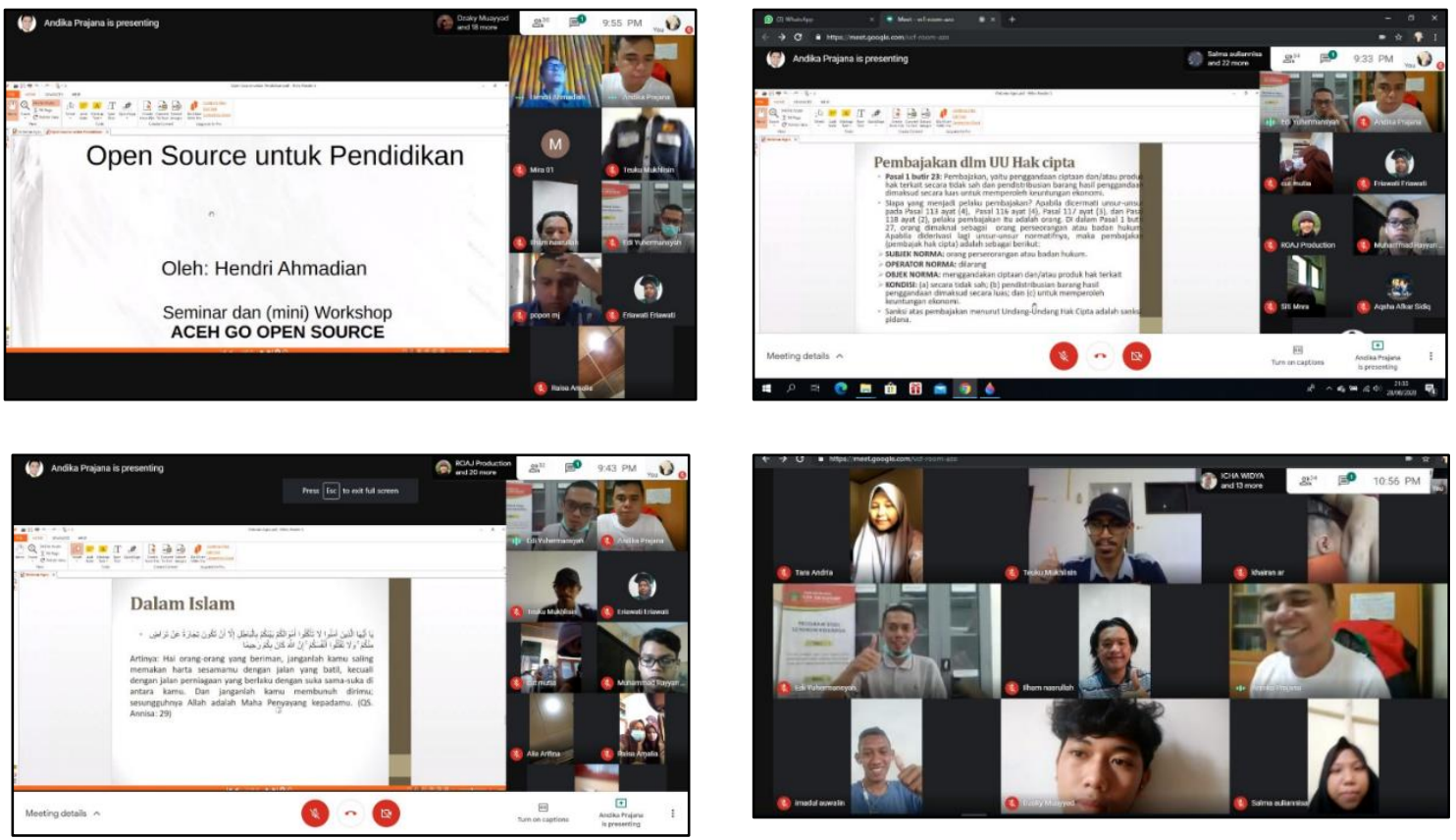

Gambar 4. Pemaparan materi seminar

Acara webinar dilaksanakan dengan sistem moderator melalui perangkat lunak google meet yang dipimpin oleh penulis sendiri, kemudian dilanjutkan dengan pembukaan secara resmi acara webinar oleh ketua Prodi. Teknologi Informasi Ibu Eriawati, M.Pd. Setelah dibuka secara resmi, acara webinar dilanjutkan dengan pemaparan materi oleh Bapak Edi Yuhermansyah, S.Hi., LLM dengan topik seminar "Hukum Menggunakan Software Bajakan". Sementara itu, pemateri kedua adalah Bapak Hendri Ahmadian, M.I.M yang mengangkat topik "Aplikasi Open Office untuk Dunia Pendidikan" melalui pemaparan praktis. Berikut beberapa tangkapan layar proses pelaksanaan webinar tersebut.

Selain melibatkan proses pendampingan komunitas oleh narasumber, penulis juga membuat buku saku yang berisi langkah-langkah praktis penggunaan beberapa perangkat lunak Open Souce, yang berisi materi: langkah praktis penggunaan perangkat lunak Open Office dan 
pemasangan system operasi Ubuntu beserta proses konfigurasinya, Seperti terlihat pada gambar di bawah ini.

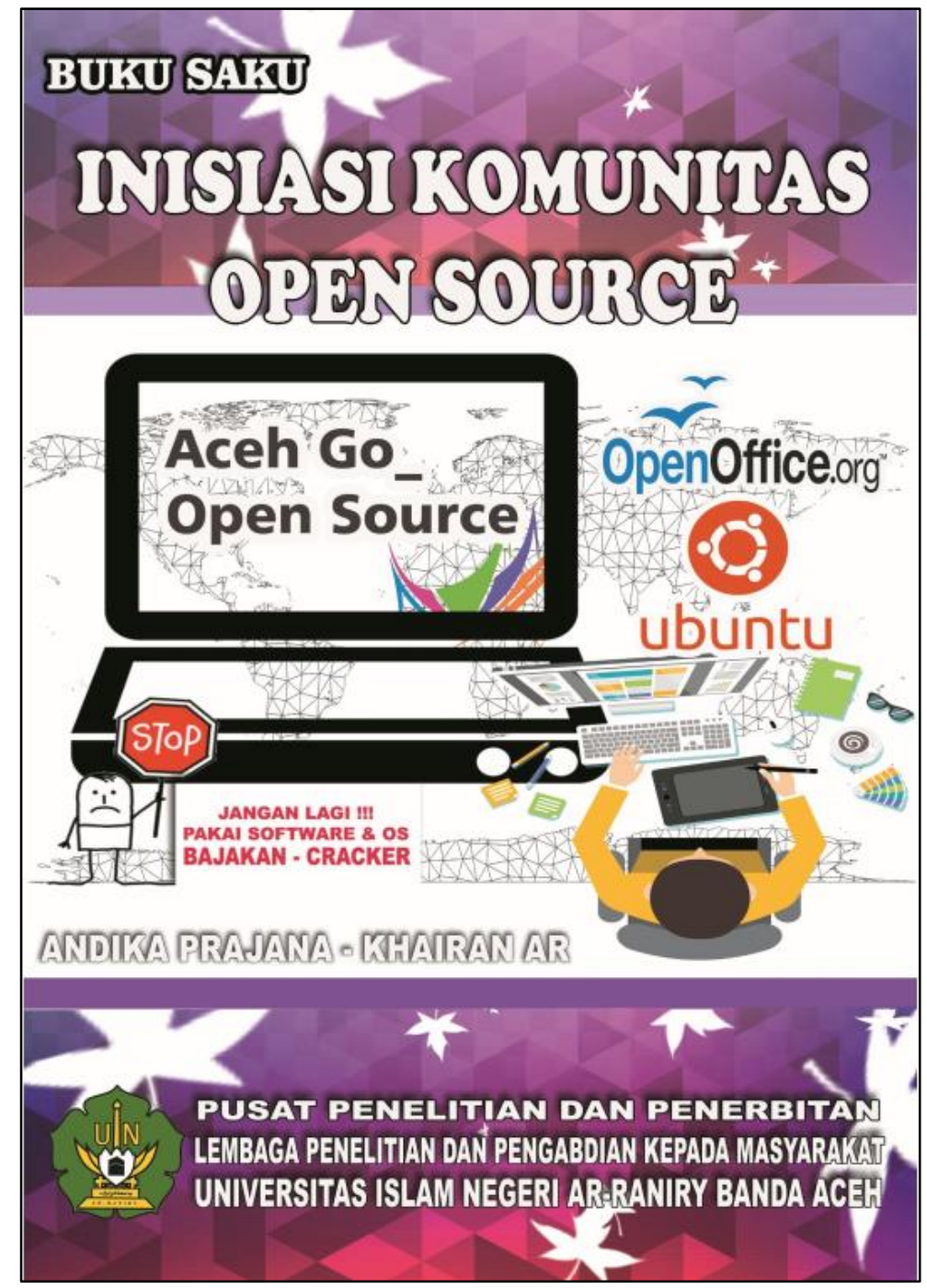

Gambar 5. Buku Saku Bagi Anggota Komunitas

Selain itu, agar anggota komunitas dapat berinteraksi dalam rangka berbagi pengetahuan tentang perangkat lunak yang dimilikinya baik pengetahuan yang bersumber dari buku-buku atau pengetahuan-pengetahuan praktis yang bersumber dari pengalaman siswa, penulis dan mahasiswa pendamping membuat website komunitas seperti terlihat pada gambar 6 .

Sementara itu, pada penelitian ini penulis mengoprasionalkan variabel-variabel knowledge sharing yang dimaksudkan untuk mengukur dampak dalam membagikan pengetahuan open source yang dilakukan oleh siswa sehingga dapat ditemukan rumusan variabel yang tepat dalam membangun komunitas perangkat lunak open source siswa madrasah di Aceh. Pengukuran ini, penulis lakukan dengan pendekatan statistik bertipe deskriptif kuantitatif. Karena proses pengukuran dampak Pengabdian yang penulis lakukan belum dapat ditentukan hasil prediksinya, maka penulis memanfaatkan salah satu model pendekatan statistik berbasis prediksi yakni model PLS-SEM. 


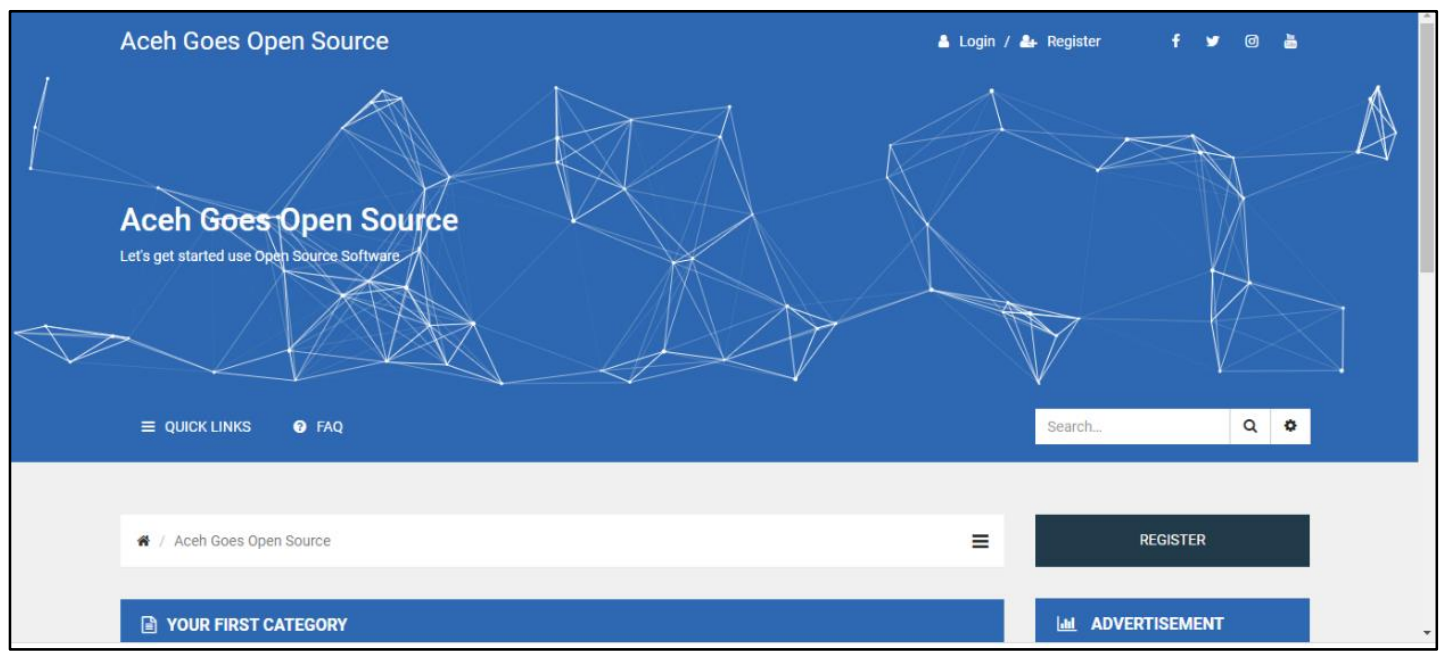

Gambar 6. Website Komunitas

Pada pengabdian yang penulis lakukan ini, yang menjadi responden pengabdian adalah siswa-siswa madrasah binaan Kemenag provinsi Aceh. Proses pemilihan besaran responden penelitian adalah dengan menerapkan teori chin, yakni dengan mencari jumlah indikator terbanyak pada konstruk laten model pengabdian, kemudian dikalikan dengan 10 (Chin, 1998)

Berdasarkan pada konstruk laten model pengabdian yang peneliti lakukan, konstruk laten organizational structure (OS) memiliki jumlah indikator terbanyak yakni berjumlah enam indikator. Berdasarkan pada jumlah indikator tersebut, maka berdasarkan teori chin jumlah responden pada penelitian ini adalah minimal 60 siswa.

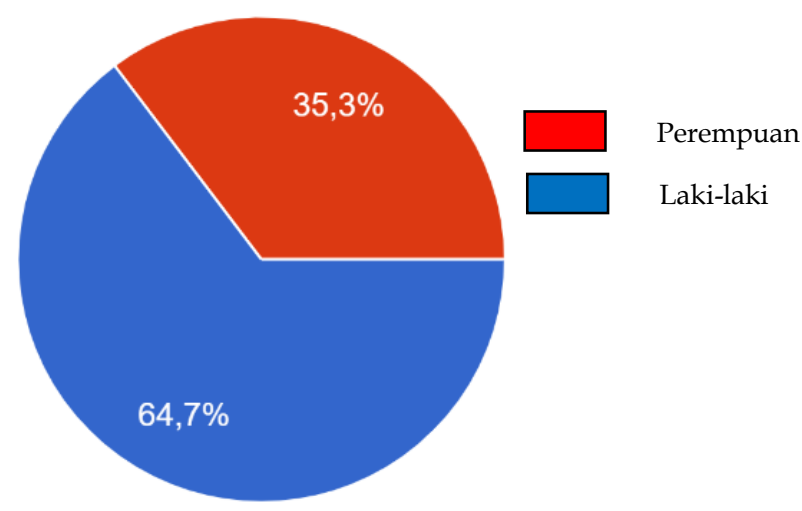

Gambar 7. Sebaran Jenis Kelamin Pengisi Kuesioner

Jumlah siswa yang mengisi kuesioner berjenis kelamin laki-laki adalah sebanyak 64,7\% berjenis kelamin laki-laki, sedangkan jumlah responden berjenis kelamin perempuan adalah sebanyak $35,3 \%$ yang dapat dilihat pada gambar 2 . Selain itu, penulis juga memetakan perangkat lunak bajakan yang sering dan masih digunakan oleh siswa-siswa madrasah binaan Kemenag provinsi Aceh, seperti terlihat pada gambar 3. 


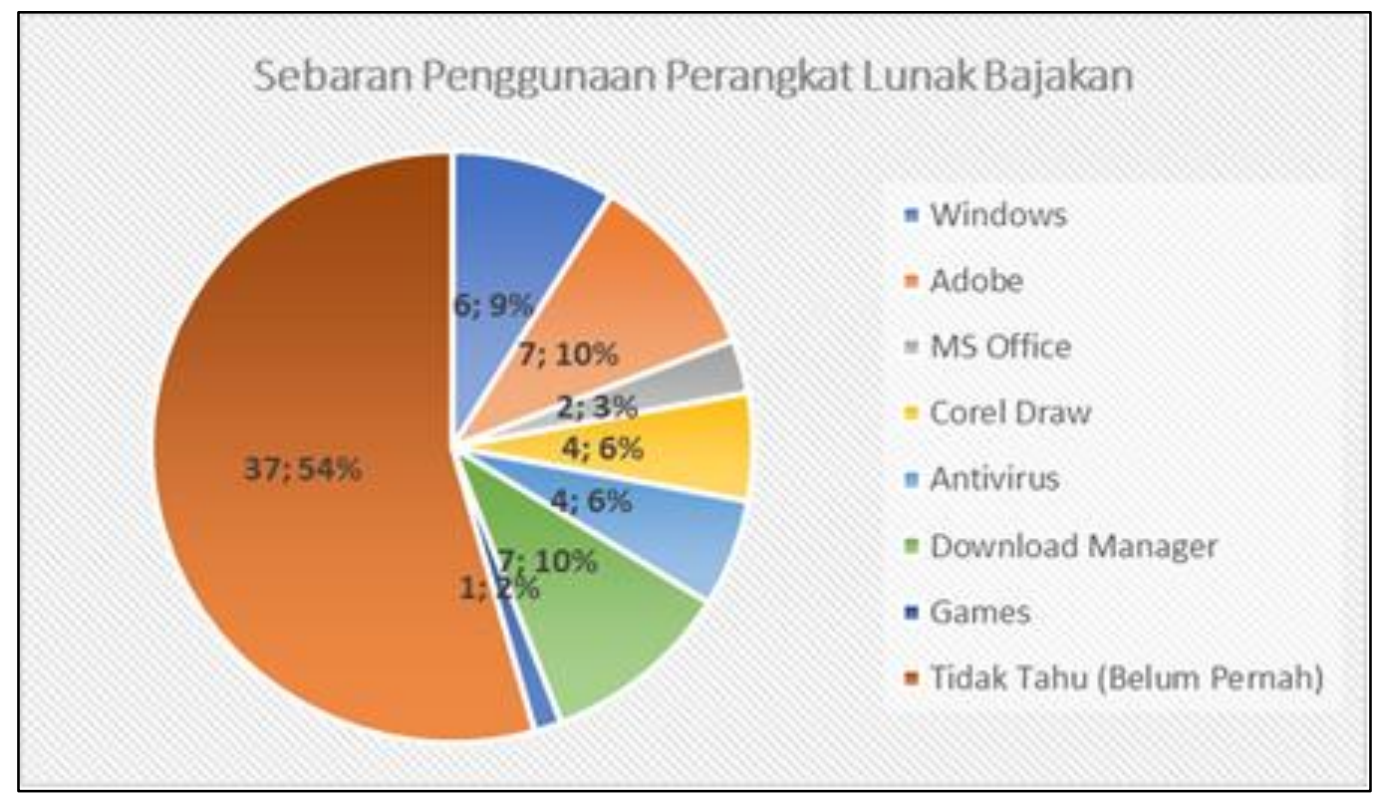

Gambar 8. Sebaran Penggunaan Perangkat Lunak Bajakan

Berdasarkan pada sebaran grafik di atas, dapat dilihat bahwa perangkat lunak bajakan tertinggi yang banyak digunakan oleh siswa adalah perangkat lunak keluaran Adobe dan perangkat lunak download manager yakni sebesar 10\%. Sementara itu, windows bajakan menepati urutan ke tiga yakni sebesar $9 \%$. Namun, sedikit mengejutkan karena hamper $54 \%$ siswa menjawab tidak tahu tentang perangkat lunak yang mereka gunakan adalah perangkat lunak bajakan. Artinya, 54\% siswa madrasah yang diteliti bias jadi menggunakan perangkat lunak bajakan namun mereka tidak mengetahui bahkan memahami apakah perangkat lunak yang mereka gunakan tersebut bajakan atau tidak. Hal tersebut mengindikasikan bahwa kegiatan-kegiatan yang serupa dengan pengabdian ini perlu dilakukan secara berkesinambungan guna memberikan pemahaman yang lebih mendalam kepada para siswa madrasah di aceh.

\section{Evaluasi Model Pengukuran}

Berdasarkan pada alur pengabdian yang telah penulis gambarkan pada tabel 1 sebelumnya, terdapat lima variabel yang penulis uji yakni: Trust \& Community Leader, Shared Vision \& Self Efficiency, Organizational Structure, Help Other \& Reciprocal Benerfit, dan Attitude $\&$ Religious. Pengujian ini penulis lakukan untuk melihat apakah proses berbagi pengetahuan pada komunitas pengabdian yang penulis bentuk dapat berjalan sesuai dengan yang penulis harapkan berdasarkan pada lima variabel tersebut, serta dapat memberikan dampak yang signifikan yang bersifat berkelanjutan bagi komunitas. Untuk menguji hal tersebut, penulis memanfaatkat pendekatan berbasis prediksi menggunakan metode Partial Least Square (PLS). 


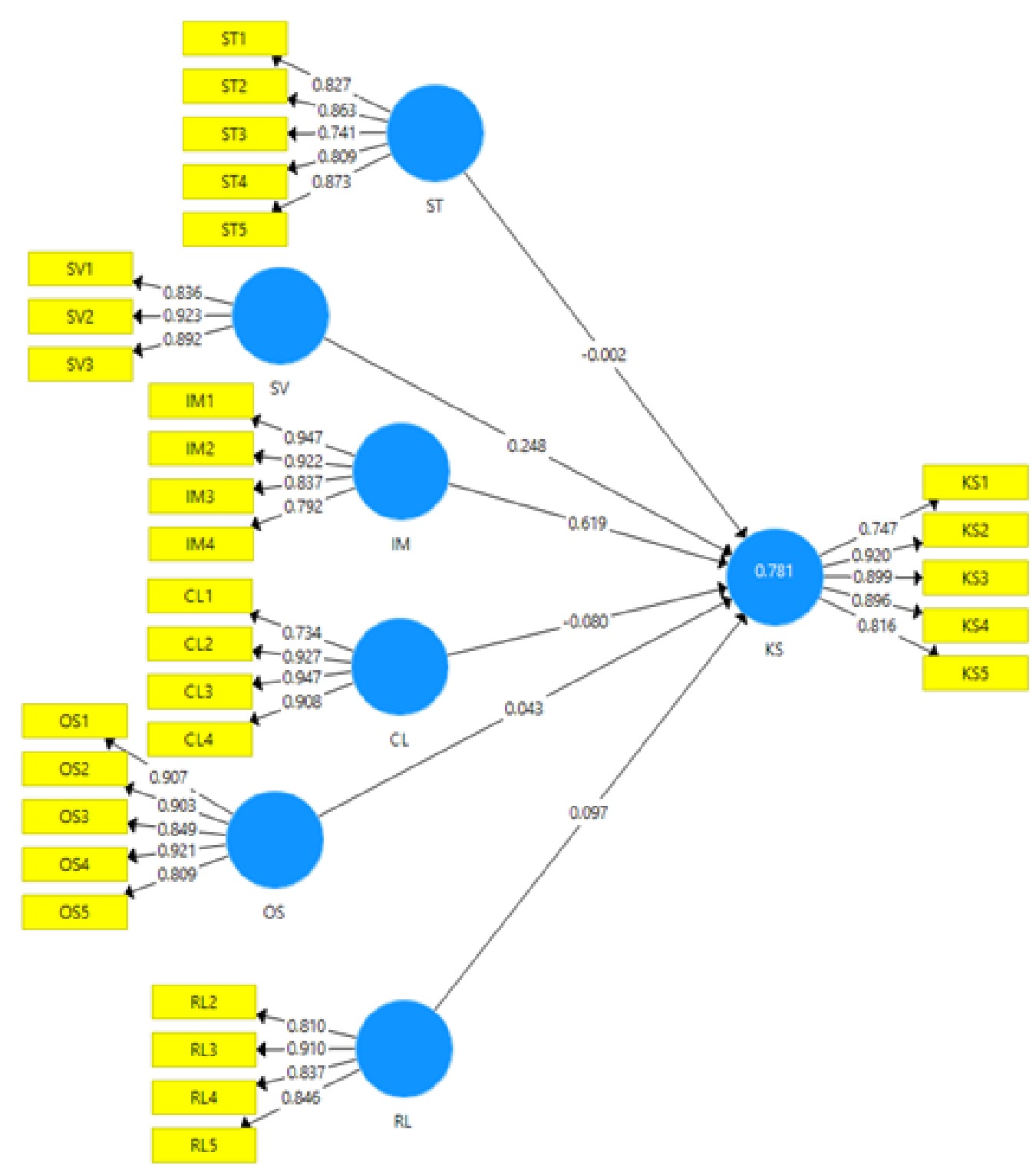

Gambar 9. Pengujian Validasi Data

Sebagai tahapan awal dalam pengujian, penulis melakukan standar pengujian PLS tahap awal yakni melihat nilai validitas penggunaan keseluruhan operasional variabel yang penulis angkat. Proses validitas ini merupakan salah satu proses PLS dalam tahapan evaluasi model pengukuran atau biasa dikenal dengan istilah Outer Model. Evaluasi model pengukuran bertujuan melihat kesamaan nilai bagian luar antara indikator terhadap variabelnya (konstruk laten). Untuk melihat hasil validitas keseluruhan indikator terhadap konstruk latennya, penulis dasarkan pada nilai Average Variance Extracted (AVE) yang merupakan salah satu bentuk penilaian validitas dalam metode PLS, dengan aturan: jika nilai indikator terhadap konstruk latennya lebih besar dari $0,5(>0,5)$ maka indikator tersebut dikatakan valid. Setelah dilakukan pengujian validitas, penulis memperoleh hasil seperti yang disajikan pada Gambar 9. Berdasarkan pada sebaran nilai diagram pada Gambar 9, dapat dilihat bahwa keseluruhan nilai lebih besar dari standar nilai AVE yang ditetapkan yakni di atas 0,5. Maka dapat disimpulkan bahwa, keseluruhan variabel yang penulis telah tentukan sebelumnya bernilai valid, serta dapat penulis operasionalkan pada pengabdian ini. 


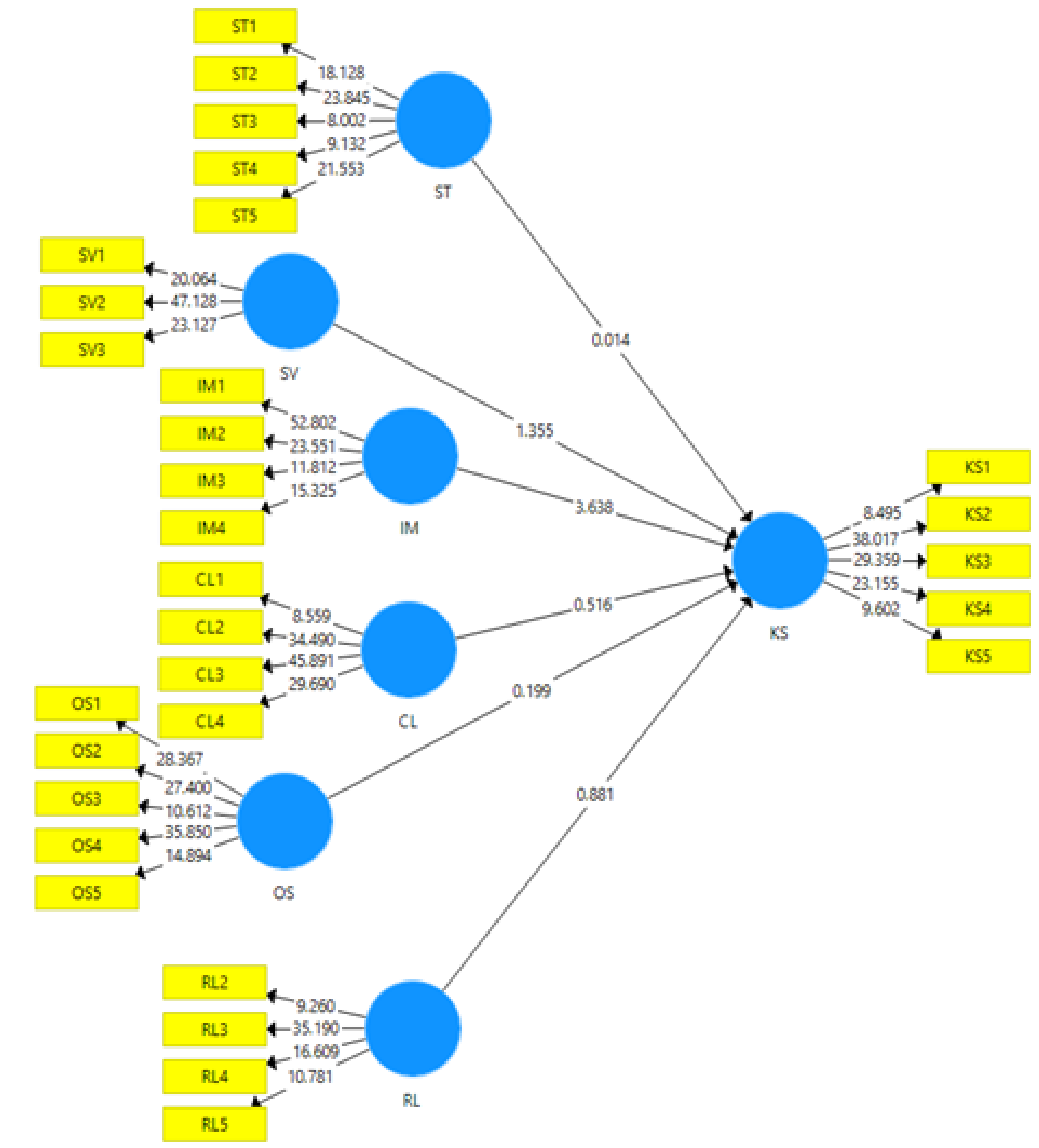

Gambar 10. Nilai t-Statistics setelah proses Bootstrapping

Disamping menguji validitas variabel, penulis juga menguji besaran pengaruh antar konstruk laten yang penulis operasionalkan. Hal ini bertujuan untuk menjawab hipotesis awal apakah ke lima variabel yang penulis operasionalkan saling mempegaruhi atau tidak. Untuk itu, penulis menggunakan uji-t dengan standar nilai $t$-value sebesar 1,96 . Setelah dilakukan pengujian diperoleh hasil seperti terlihat pada gambar 10.

Berdasarkan pada nilai uji-t pada diagram gambar 10, diketahui bahwa hanya terdapat satu konstruk laten saja yang memiliki nilai lebih besar dari standar nilai $t$-value sebesar 1,96 yakni konstruk laten individual motivation dengan nilai sebesar 3,638. Sehingga dapat disimpulkan bahwa dari kelima variabel yang penulis operasionalkan variabel individual motivation memiliki pengaruh yang signifikan terhadap keinginan berbagi pengetahuan antar siswa madrasah di Aceh. 


\section{Jalur Hipotesis}

Didasarkan pada hasil pengujian hipotesis di atas, berikut penulis berikan gambaran jalur hipotesis yang diterima, yang penulis tandai dengan garis biru tebal.

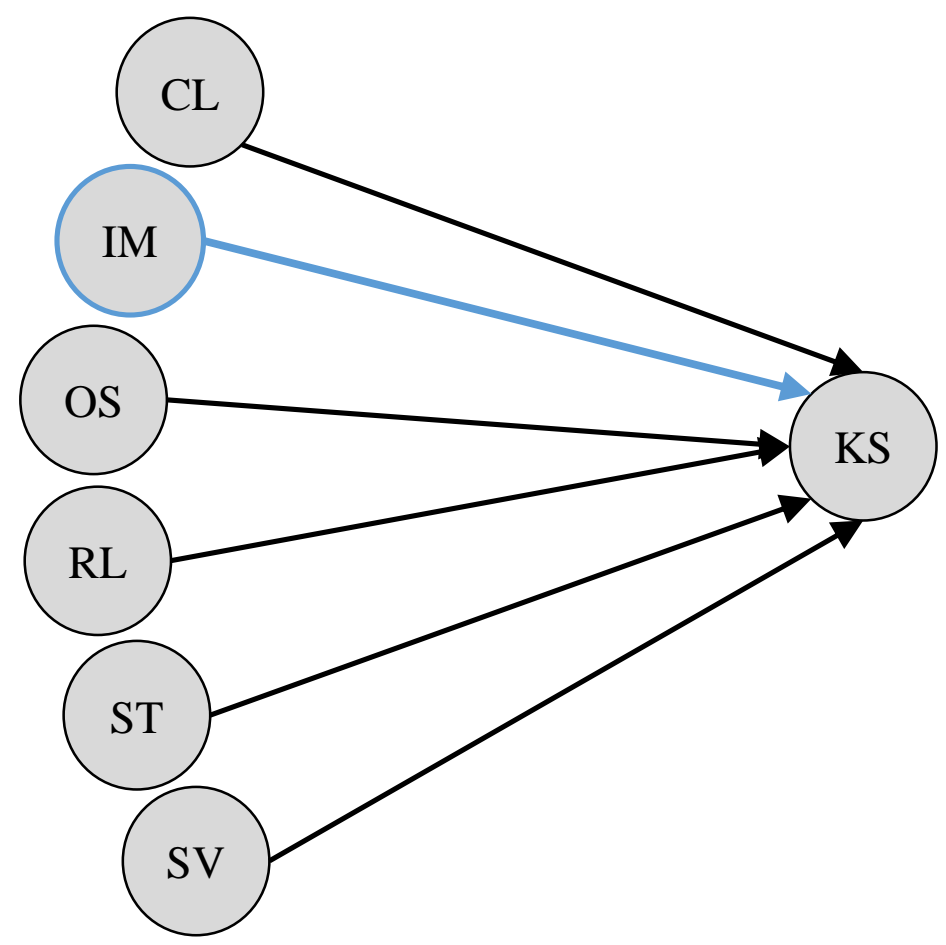

Gambar 11. Hipotesis

\section{Pengaruh Community Leader (CL) Terhadap Knowledge Sharing (KS)}

Setelah dilakukan pengujian hipotesis diperoleh hasil besar pengaruh konstruk laten $\mathrm{CL}$ terhadap konstruk laten KS sebesar 0,516 artinya, nilai tersebut masih berada di bawah nilai prasyarat -t-value 1,96. Sehingga dapat ditarik asumsi bahwa, CL tidak berpengaruh signifikan terhadap proses KS pada komunitas Aceh Go Open Source (AGOS). Hal tersebut mengindikasikan bahwa pada komunitas AGOS, peran ketua bukan pendorong utama anggota komunitas untuk berbagi pengetahuan open source yang dimiliki oleh siswa di Aceh.

\section{Pengaruh Individual Motivation (IM) Terhadap Knowledge Sharing (KS)}

Skor yang diperoleh konstruk laten IM terhadap konstruk laten KS setelah penulis melakukan pengujian hipotesis adalah sebesar 3,638. Skor ini lebih besar dari nilai prasyarat tvalue 1,96, sehingga diasumsikan bahwa hipotesis diterima, artinya IM berpengaruh signifikan terhadap KS. Hal tersebut dapat diterjemahkan bahwa anggota komunitas AGOS memiliki keinginan dan/atau dorongan dari dalam dirinya untuk membagikan pengetahuan open source yang dimiliki oleh siswa-siswa di Aceh. Temuan ini menjadi penting, karena yang menjadi dorongan utama dalam proses menumbuhkan sebuah komunitas adalah keinginan yang kuat dari dalam diri anggota komunitas untuk berbagi pengetahuan yang dimiliki.

\section{Pengaruh Organizational Structure (OS) Terhadap Knowledge Sharing (KS)}

Berdasarkan pada hasil hipotesis yang penulis temukan, konstruk laten OS tidak 
berpengaruh signifikan terhadap konstruk laten KS. Skor yang diperoleh adalah sebesar 0,199, lebih kecil dari nilai prasyarat 1,96. Hal tersebut mengindikasikan bahwa pembentukan komunitas open source dengan struktur komunitas yang terpilih secara aklamasi bukan menjadi isu utama dalam mewujudkan sebuah sistem komunitas open source antar siswa di Aceh. Temuan ini sejalan dengan hasil Pengabdian Kyeong Nam Yeon dan kawan-kawan yang dilakukan pada pusat informasi Pengabdian biologi korea. Mereka menyatakan bahwa faktor struktural tidak berpengaruh signifikan dalam proses berbagi pengetahuan antar pegawai di pusat informasi pengabdian korea tersebut (Yeon, dkk, 2016).

\section{Pengaruh Religious (RL) Terhadap Knowledge Sharing(KS)}

Berdasarkan hasil uji hipotesis yang penulis lakukan, ditemukan bahwa konstruk laten RL tidak berpengaruh signifikan terhadap konstruk laten KS. Skor yang penulis dapatkan dalam uji hipotesis adalah sebesar 0,881 , nilai tersebut lebih rendah jika dibandingkan dengan nilai yang telah ditetapkan yakni sebesar 1,96. Artinya RL tidak berpengaruh signifikan terhadap KS. Temuan ini cukup mengejutkan karena hampir keseluruhan sampel Pengabdian merupakan siswa-siswa yang berada di bawah naungan Kementerian Agama yang tentu saja mengetahui hadist dan/atau ayat Al-Quran yang memerintahkan pelarangan untuk memakan hak orang lain. Namun berdasarkan jawaban pertanyaan pada kuesioner yang peneliti bagikan, memang masih ada siswa yang menjawab bahwa penggunaan perangkat lunak berlisensi secara tidak resmi masih berguna, karena tingginya harga beli perangkat lunak berlisensi tersebut.

\section{Pengaruh Social Trust(ST) terhadap Knowledge Sharing(KS)}

Setelah dilakukan pengujian hipotesis, diperoleh skor 0,014 untuk konstruk laten ST terhadap konstruk laten KS, lebih kecil dari skor prasyarat yang telah ditatapkan yakni sebesar 1,96. Hal ini berarti bahwa ST tidak berpengaruh signifikan terhadap KS dalam upaya mendorong keinginan berbagi pengetahuan open source pada komunitas AGGOS. Temuan ini bertolak belakang dengan hasil Pengabdian Kyeong Nam Yeon dan kawan-kawan yang menyatakan bahwa, ST berpengaruh signifikan terhadap KS.

\section{Pengaruh Share Vision (SV) Terhadap Knowledge Sharing (KS)}

Berdasarkan pada hasil uji hipotesis yang peneliti lakukan, konstruk laten SV terhadap konstruk laten KS memperoleh skor 1,355, lebih rendah dari nilai prasyarat yakni sebesar 1,96. Hal tersebut mengindikasikan bahwa konstruk laten SV tidak berpengaruh signifikan terhadap konstruk laten KS dalam upaya untuk mendorong keinginan membagi pengetahuan open source yang dimiliki oleh anggota komunitas AGGOS. Hasil Pengabdian ini bertolak belakang dengan temuan Kyeong Nam Yeon dan kawan-kawan yang menyatakan bahwa SV memiliki pengaruh yang signifikan terhadap KS.

\section{Kesimpulan}

Terdapat dua penyelesaian pengabdian yang peneliti lakukan, yakni: pelaksanaan sosialisasi penggunaan perangkat lunak open source yang dilakukan oleh narasumber yang berkompeten disertai dengan pembentukan komunitas Aceh Go Open Source (AGGOS) dan 
pengukuran dampak pembentukan komunitas AGOS yang peneliti lakukan dengan pendekatan statistik model PLS-SEM.

Untuk proses pengukuran, pengabdi mendapatkan temuan bahwa konstruk laten Individual Motivatian (IM) merupakan indikator yang berpengaruh signifikan terhadap keinginan anggota komunitas AGOS dalam rangka membagikan pengetahuan yang mereka miliki, dengan skor yang diperoleh sebesar 3.638 lebih tinggi dari nilai t-value yang telah di tetapkan yakni sebesar 1,96. Hal tersebut menjadi poin positif, karena konstruk IM membuktikan bahwa keinginan anggota komunitas AGGOS untuk membagikan pengetahuan open source yang mereka miliki sangat tinggi. Sementara itu, lima konstruk laten lainnya yang peneliti uji, tidak berpengaruh secara signifikan terhadap keingianan berbagi pengetahuan open source antar anggota komunitas AGGOS dengan rincian skor: Social Trust (ST) sebesar 0,014, Share Vision (SV) sebesar 1,355, Community Leader (CL) sebesar 0,516, Organizational Structure (OS) sebesar 0,199, dan Religious (RL) 0,881.

Perlu dilakukan pengukuran dalam bentuk lain, selain menggunakan pendekatan PLSSEM, misalnya dengan penggunaan regresi linier dengan teknik pengujian hipotesis lainnya semisal uji F. Disamping itu, diperlukan kajian yang lebih mendalam lagi tentang operasional konstruk laten dengan besaran sampel penelitian lebih besar dari 68 sampel penelitian. Khusus untuk pembentukan komunitas, mungkin harus ditambahkan lagi jumlah intensitas seminar dan/atau pelatihan serta pemberian materi kepada siswa, untuk lebih memahamkan lagi penggunaan perangkat lunak open source beserta aturan-aturan yang menyertainya, terutama aturan tentang hukum positif dan keagamaan, yang dapat menjadi alternatif perangkat lunak bajakan yang tentu saja selain memiliki fungsi yang sama dengan perangkat lunak bajakan, juga menjadi kunci dalam menjalankan aturan-aturan Allah SWT yang diperintahkan dalam kitab suci Al-Qur'an untuk selalu menjauhkan diri dari perbuatan mengambil hak orang lain.

\section{Referensi}

Business Software Alliance (BSA). (2017). General Counsel Forum. Diakses di https://www.bsa.org/news-events/events/2017-general-counsel-forum

Chin, W. W. (1998). The partial least squares approach to structural equation modeling. Modern methods for business research, 295(2), 295-336.

Gopal, R. D., \& Sanders, G. L. (1998). International software piracy: Analysis of key issues and impacts. Information Systems Research, 9(4), 380-397. https://doi.org/10.1287/isre.9.4.380

Goel, R. K., \& Nelson, M. A. (2009). Determinants of software piracy: Economics, institutions, and technology. The Journal of Technology Transfer, 34(6), 637-658.

Majid, B. A., Vivianie, S., \& Yusuf, B. (2018). Studi Evaluasi Penggunaan Software Bajakan Di Kalangan Mahasiswa Ftk Uin Ar-Raniry. Cyberspace: Jurnal Pendidikan Teknologi Informasi, 2(1), 37-47.

Marron, D. B., \& Steel, D. G. (2000). Which countries protect intellectual property? The case of software piracy. Economic inquiry, 38(2), 159-174.

Microsoft. (2020). Diakses di: https://www.microsoft.com

Prajana, A. (2017). Pemanfaatan Perangkat lunak Whatsapp Untuk Media Pembelajaran Dalam Lingkungan Uin Ar-Raniry Banda Aceh. Cyberspace: Jurnal Pendidikan Teknologi Informasi, 1(2), 122. https://doi.org/10.22373/cs.v1i2.1980

Ukhisia, B. G., Astuti, R., \& Hidayat, A. (2013). Analisis Pengaruh Keselamatan dan Kesehatan Kerja terhadap Produktivitas Karyawan dengan Metode Partial Least Squeres. Malang: Jurnal 
Teknologi Pertanian, 14(2).

Wulandari, R. W., Maryani, N. (2020). Peningkatan Keterampilan Guru SMA Terbuka Melalui Pelatihan Pembuatan E-Media. Jurnal Qardhul Hasal: Media Pengabdian Masyarakat, 6(1), 3948. http://dx.doi.org/10.30997/qh.v6i1.2557

Yeon, K., Wong, S. F., Chang, Y., \& Park, M. C. (2016). Knowledge sharing behavior among community members in professional research information centers. Information Development, $32(3), 655-672$. 